\title{
A FUNDAMENTAÇÃO SUBJETIVA E SOCIAL DA RELIGIÃO EM LUDWIG FEUERBACH E KARL MARX
}

\author{
Eduardo F. Chagas ${ }^{1}$
}

\begin{abstract}
Resumo:
O presente artigo pretende explicitar a diferença entre as concepções de religião em Ludwig Feuerbach e Karl Marx, no intuito de compreender por que a religião tornou-se, novamente, uma questão atual. Incialmente, mostrar-se-á a fundamentação subjetiva da religião em Feuerbach, principalmente em sua obra principal, A Essência do Cristianismo, em que ele deixa claro que o Cristianismo coloca no seu cume um deus subjetivo, pessoal, ilimitado, que cria através do "puro pensar" e do "querer" a natureza e o homem. Em seguida, diferentemente das argumentações de Feuerbach, evidenciar-se-á a fundamentação social da religião em Marx. Embora não haja no pensamento de Marx uma elaboração sistemática acerca da religião, há uma crítica a ela enquanto crítica social das condições materiais de existência, que é o fundamento dela. Para Marx, a religião, entendida especificamente como superstição, idolatria, "ópio", que conforma o homem e embaraça a sua consciência, deve ser negada, mas não se trata pura e simplesmente de um desprezo, de uma proibição ou perseguição à religião, nem tampouco de uma negação em geral a ela, uma vez que ela é uma questão privada e deve ser respeitada, mas de desvelar o véu religioso presente na sociedade e no seu ordenamento político, no Estado, que oculta a exploração e a opressão humana. A crítica à religião como crítica da realidade social, da qual ela nasce e é expressão ideal, contribui, de certa forma, para a emancipação social do homem. Por último, procurar-se-á refletir sobre o lugar e a função da religião dentro de seu contexto sócio-político-econômico, no intuito de compreender melhor, por exemplo, o papel dela nas diferentes crises no mundo atual.
\end{abstract}

Palavras-chave: Religião em Feuerbach e Marx. O Fundamento da Religião em Feuerbach e Marx. A Diferença da Religião em Feuerbach e Marx.

\section{THE SUBJECTIVE AND SOCIAL FOUNDATION OF RELIGION IN LUDWIG FEUERBACH AND KARL MARX}

\begin{abstract}
:
This article aims at discussing the difference between conceptions of religion as propounded by Ludwig Feuerbach and Karl Marx, in the effort to understand why religion has once again become a current issue. Initially, the subjective foundation of religion in Feuerbach will be shown principally in his fundamental

1 Graduado em Filosofia pela Universidade Estadual do Ceará (UECE, 1989), Mestrado em Filosofia pela Faculdade de Filosofia e Ciências Humanas (FAFICH) da Universidade Federal de Minas Gerais (UFMG, 1993) e Doutorado em Filosofia pela Universität von Kassel (KASSEL, ALEMANHA, 2002). É professor efetivo (associado) do Curso de Filosofia e do Programa de Pós-Graduação em Filosofia da Universidade Federal do Ceará (UFC) e professor colaborador do Programa de PósGraduação em Educação Brasileira da FACED - UFC. Coordenador do Grupo de Estudos Marxistas GEM -, vinculado ao Eixo Marxismo, Teoria Crítica e Filosofia da Educação, e ao Programa de PósGraduação em Educação Brasileira da FACED - UFC. Orientador do Programa Jovens Talentos/CNPQ. Atualmente, é Pesquisador Bolsista de Produtividade do CNPQ, é membro da Internationale Gesellschaft der Feuerbach-Forscher (Sociedade Internacional Feuerbach) e dedica suas pesquisas ao estudo da filosofia política, da filosofia de Hegel, do idealismo alemão e de seus críticos Feuerbach, Marx, Adorno e Habermas. E-mail: ef.chagas@uol.com.br. Homepage: www.efchagas.wordpress.com . Academia.edu: https://ufc.academia.edu/EduardoFChagas. Plataforma Google Scholar ou Google Acadêmico: http://scholar.google.com.br/citations?user=yBsqblIAAAAJ\&hl=pt-BR. Editor da Revista Dialectus http://www.revistadialectus.ufc.br/index.php/RevistaDialectus/about/editorialPolicies\#sectionPolicies. Lattes: http://lattes.cnpq.br/2479899457642563.
\end{abstract}




\section{A FUNDAMENTAC̄̃̃O SUBJETIVA E SOCIAL DA RELIGIÃO... Eduardo F. Chagas}

work, The Essence of Christianity, in which he makes it clear that Christianity places on its summit a subjective, personal, unlimited God who creates through "pure thinking" and "will" nature and man. Then, unlike Feuerbach's arguments, the social basis of religion in Marx will be shown. Although there is no systematic elaboration of religion in Marx's thought, there is an evaluation of it according to a social critique of the material conditions of existence, which establishes the foundation of it. For Marx, religion, specifically presented as superstition, idolatry, "opium," which conforms man and embarrasses his conscience, must be denied, but it is not utterly contempt, prohibition or persecution of religion, nor its denial in a general approach, since it is a private matter and must be respected, but to unveil the religious veil present in society and in its political order in the State, which conceals human exploitation and oppression. The criticism of religion as an assessment of social reality from which it is born and is an ideal expression contributes in a certain way to the social emancipation of man. In closing, the article will seek to reflect on the place and function of religion according to its social political and economic context in order to better understand, for example, its role in the many crises in the world today.

Keywords: Religion in Feuerbach and Marx. Fundament of Religion in Feuerbach and Marx. Difference of Religion in Feuerbach and Marx.

\section{A ANTROPOMORFIZAÇÃO DE DEUS NA RELIGIÃO CRISTÃ SEGUNDO FEUERBACH}

Com deus (Gott) está associado um nome que o homem usa para expressar ou a sua própria essência ou a essência da natureza. Partindo, inicialmente, da tese, que veremos a seguir, a saber, que deus e o homem são, no Cristianismo, idênticos, Feuerbach revela que o segredo (Rätsel) recôndito da teologia cristã é nada mais do que a antropologia (Anthropologie) ou, melhor dizendo, que o conteúdo do ser infinito (in abstrato) (deus) é o ser finito (in concreto) (o homem). No Cristianismo, o homem (Mensch) se concentra apenas em si mesmo e faz de si uma essência absoluta e sobrenatural, ou seja, um deus.

Assim, deus é a essência declarada, anunciada, do sujeito como objeto absoluto. Em oposição a Hegel, que afirma, em sua filosofia da religião, que o saber do homem acerca de deus é o saber de deus acerca de si mesmo, postula Feuerbach, para transformar a teologia em antropologia, o princípio oposto que reza: o conhecimento do homem de deus é o saber do homem de si mesmo; não foi deus que criou o homem, mas o homem quem criou deus a sua imagem e semelhança. ${ }^{2}$ Apoiando-se em Homero, escreve Feuerbach, os

2 No artigo Zur Beurteilung der Schrift "Das Wesen des Christentums" (1842), Feuerbach elucida da seguinte maneira a diferença entre a filosofia de Hegel e a sua: "Minha filosofia da religião é tão pouco uma explikation da hegeliana, [...] que ela deve ser concebida e julgada, pelo contrário, apenas como opposition. O que, a saber, tem em Hegel o significado do secundário, do subjetivo, do formal, isso tem para mim o significado do primitivo, do objetivo, do essencial. Segundo Hegel, o sentimento, o afeto, o coração é, por exemplo, a forma, na qual se deve submergir o conteúdo derivado da religião, com isto ela torna-se propriedade do homem; para mim, o objeto, o conteúdo do sentimento religioso é nada mais do que a essência do sentimento." (FEUERBACH, 1970, p. 229-230).

\begin{tabular}{|l|l|l|l|l|}
\hline Qovista Qialectus & Ano 5 & n. 12 & Janeiro - Julho 2018 & p. 8-35 \\
\hline
\end{tabular}




\section{A FUNDAMENTACÃ̃ SUBJETIVA E SOCIAL DA RELIGIÃO... \\ Eduardo F. Chagas}

deuses são seres que só existem para e através dos homens; por isso não velam o homem quando este dorme, mas quando os homens dormem, dormem também os deuses, isto é, com a consciência do homem se esvai também a existência dos deuses. (FEUERBACH, 1967, p. 99).

Conquanto Feuerbach conclua disso que a consciência do homem de deus é a sua autoconsciência, chama ele mesmo atenção para o fato de que o homem religioso não é a si imediatamente consciente de que sua consciência de Deus é a própria consciência de sua essência, porque a ausência dessa consciência fundamenta de facto a essência da religião cristã. Destarte, ele designa a religião em geral apenas como contemplação (Anschauung) "infantil", "fantástica" da essência humana, ou seja, como a primeira e indireta autoconsciência do homem. Na religion, o homem não vê, porém, em si mesmo sua essência (a humanidade, o gênero), mas fora de si mesmo, pois sua própria essência é a ele objeto como uma outra essência. Melhor dizendo: ele realiza nela sua essência, embora ele não reconheça o objeto como produto de sua atividade. A intention de Feuerbach, particularmente frente a religião, que considera seu objeto como sobrehumano, consiste em provar que a oposição entre o divino (sagrado) e o humano (profano) é ilusória (illusorisch), porquanto o conteúdo da religião (cristã) é inteiramente humano. Todas as declarações sobre deus são para ele apenas afirmações sobre o homem, pois na medida em que deus é aquilo o que o homem é, a saber, uma essência sensível, viva, afetuosa, podem ambos (deus e o homem) serem reconhecidos, portanto, apenas partindo desta essência.

A acepção antropológica de deus, isto é, a reduktion da teologia (Theologie) em antropologia (Anthropologie) ou da essência universal de deus na essência natural do homem é o ponto central em torno do qual gira a obra principal de Feuerbach, A Essência do Cristianismo (Das Wesen des Christentums). Para Feuerbach, o deus cristão significa nada mais do que o proceder do homem frente a si mesmo, considerado como um ser diverso dele, existente para si, livre, então, de sua corporeidade (Leiblichkeit) e finitude (Endlichkeit). Todas as qualidades "da essência divina são", como Feuerbach acentua, "determinações humanas” (FEUERBACH, 1973, p. 49.); deus e o homem são um, pois deus não é um ser sem determinação, despojado das qualidades humanas, porque a negation de tais determinações significaria igualmente a incognoscibilidade, a irreconhecibilidade e indeterminidade de deus.

Um ser sem qualidade é um ser sem objetividade, e um ser sem objetividade

é um ser nulo. Por isso, quando o homem retira de deus todas as qualidades, é

\begin{tabular}{|l|l|l|l|l|}
\hline Q Rovista Dialectus & Ano 5 & n. 12 & Janeiro - Julho 2018 & p. 8-35 \\
\hline
\end{tabular}




\section{A FUNDAMENTAC̄̃̃O SUBJETIVA E SOCIAL DA RELIGIÃO... \\ Eduardo F. Chagas}

este deus para ele apenas um ser negativo, nulo. Para o homem realmente religioso não é deus um ser sem atributos, porque é para ele um ser certo, real. (FEUERBACH, 1973, p. 49).

O ser, que realmente é, tem uma existência qualitativa, determinada e, por isso, finita. Esta position de Feuerbach é uma refutação (Widerlegung) direta à concepção de deus como uma existência universal, transcendente, isto é, como uma existência sem qualidade, que é, todavia,

o fogo, o oxigênio, o sal da existência. Uma existência em geral, uma existência sem qualidade, é uma existência insípida, uma existência sem gosto. [...] Somente quando o homem perde o sabor da religião, quando a própria religião se torna insípida, só então torna-se também a existência de deus uma existência insípida.” (FEUERBACH, 1973, p. 51).

Por conseguinte, Deus não é nenhuma ser em si, isto é, nenhuma existência autônoma, uma vez que ele é possível só através de determinadas qualidades, que são determinações finitas, particularmente humanas. Se o homem existe, precisamente, apenas como um ser determinado e corresponde ao critério ou à medida da existência de deus, este é, de certo modo, para ser concebido como uma "existência determinada", então como uma essência humana ou, pelo menos, como semelhante ao homem; ele está qualitativamente determinado no homem, assim ele não tem nenhuma outra representação a não ser humana. "Mas deus não é”, como Rawidowicz observa, "o homem empírico, ele é, ao contrário, 'o próprio sentimento do homem livre de todas as repugnâncias."” (RAWIDOWICZ, 1964, p. 95). Partindo dessa ponderação, a saber, que os predicados atribuídos a deus, como onipotência, onisciência, onipresença, justiça, amor, bondade, são conceitos do gênero humano, puramente antropomorfismos, Feuerbach quer superar não só a discórdia, ou seja, a oposição entre deus e o homem, mas também a causa desta cisão entre ambos, isto é, a teologia mesma.

Deus não é originariamente nenhum nome próprio, nenhum ser em si e por si, mas essencialmente uma qualidade determinada por um outro ser; nenhum sujeito, mas predicado, nada mais do que uma expressão do sentimento e da fantasia humana; isto é, não é o ser de deus enquanto tal, mas a determinidade do mesmo sua verdadeira essência. Se a "existência de deus", para poder ser, precisa de predicados, ela tem separada deles, tão-somente uma existência abstrata, isto é, ela não possui nenhuma certeza (Gewissenheit) imediata, absoluta ou objetiva. A negation dos predicados é simultaneamente a negação de deus, pois aquilo que constitui uma existência (ou um

\begin{tabular}{|l|l|l|l|l|}
\hline Qevista Dialectus & Ano 5 & n. 12 & Janeiro - Julho 2018 & p. 8-35 \\
\hline
\end{tabular}




\section{A FUNDAMENTAC̄̃̃O SUBJETIVA E SOCIAL DA RELIGIÃO... \\ Eduardo F. Chagas}

sujeito), isso se encontra apenas no predicado. Isso é mui evidente na teologia cristã, na qual os predicados manifestam a verdade e a realidade do sujeito. A propósito, Feuerbach destaca a diferença entre os significados do sujeito e do objeto e nega a autonomia (Selbständigkeit) dos predicados divinos, pois para ele tais predicados são simplesmente qualidades humanas, adoradas, no entanto, como essências sublimes, universais e absolutas. "Deus é o conceito da majestade, a mais alta distinção; o sentimento religioso é o mais alto sentimento de conveniência." (FEUERBACH, 1973, p. 58). Mas não por meio de uma natureza puramente divina, isto é, não por si mesmo, mas apenas através de determinações humanas pode deus, como mostrado, ser reconhecido. Aquilo o que vale à religião como deus ou absoluto é, então, não deus, mas o homem mesmo, concebido como uma outra essência ou como uma essência diferente dele. A religião não tem, por conseguinte, nenhum conteúdo aparte, próprio ou particular; ela apenas transforma "inconsciente" as determinações do homem em um ser autônomo, divino; todavia, ela quer conscientemente anular esta identidade (Identität) e unidade (Einheit) da essência divina com a humana, pois ela acredita que deus é um ser inteiramente distinto da essência humana, porque ele, como "ser absoluto e infinito", contém uma abundância inesgotável de diferentes predicados, dos quais o homem conhece apenas uma parte. Este conceito teológico de deus é apenas uma representation sem realidade, na verdade, representação da sensibilidade, separada de todas as determinações do espaço e do tempo, através das quais um ser existente deve, primeiro, necessariamente ser localizado. Se os predicados divinos são determinações da sensibilidade humana, poder-se-ia disso deduzir que o sujeito (=deus) destes predicados é humano. Feuerbach nomeia duas determinações essenciais de tais predicados: uma é universal, metafísica, como a totalidade (Ganzheit), a infinitude (Unendlichkeit), a indeterminidade (Unbestimmtheit), e serve à religião como um princípio absoluto; a outra é particular, pessoal, como o amor (Liebe), a justiça (Gerechtigkeit), a virtude (Tugend), e caracteriza a essência da religião. Mas "a religião nada sabe de antropomorfismos: os antropomorfismos não são para ela antropomorfismos.” (FEUERBACH, 1973, p. 63). Os predicados, os quais o homem faz a si de deus, são já a essência de deus, pois as representações de deus não são diferentes daquilo o que ele em si é. A teologia como reflexion da religião assevera, ao contrário, a distinção entre deus e o homem, asseveração essa que tem como desígnio, como visto, apagar da consciência a unidade ou a identidade inseparável entre eles; a separação de

\begin{tabular}{|c|c|c|c|}
\hline Q Ropista Dialectus & Ano 5 & n. 12 & Janeiro - Julho 2018 \\
\hline
\end{tabular}




\title{
A FUNDAMENTAC̄̃̃O SUBJETIVA E SOCIAL DA RELIGIÃO... \\ Eduardo F. Chagas
}

deus do homem vale para ela como oposição entre a criatura (Kreatur), o ser finito, considerado como nada, e o criador (Schöpfer), o ser infinito, representado como tudo, o todo.

A consideração acima mencionada, segundo a qual o homem é nada e, consequentemente, deus é tudo, evidencia claramente que a teologia cristã encerra em si mesma uma contemplação meramente negativa, hostil ao homem. Em síntese, ela torna o homem pobre, para enriquecer deus. Feuerbach afirma que ela, em contraposição ao materialismo e ao naturalismo, não possui nenhuma consciência do limite, por isso deus encontra-se para ela fora das fronteiras da sensibilidade, das barreiras da legalidade da natureza. Apenas deus, ou melhor, o ser puro é para ela o bem, pois o homem, na medida em que está submetido à necessidade, às carências corporais, está já corrompido e é inadequado ao bem. A teologia cristã não percebe, porém, que o ser bom, que ela diviniza e adora, é a própria essência boa do homem. O que ela declara sobre deus, isso deduz ela do homem. Disso resulta que o homem é o fundamento do deus cristão, porque deus não é deus, se a ele o homem falta. Este pressuposto antropológico, a saber, que o homem é a verdadeira essência de deus e, destarte, o fundamento da religião cristã, não foi, contudo, reconhecido pela teologia cristã. A position desta reza assim:

\begin{abstract}
Deus não é o que o homem é, o homem não é o que deus é. Deus é o ser infinito, o homem, o finito; deus é perfeito, o homem imperfeito; deus é eterno, o homem transitório; deus é plenipotente, o homem impotente; deus é santo, o homem é pecador. Deus e o homem são extremos: deus é o unicamente positivo, o âmago de todas as realidades, o homem é o unicamente negativo, o cerne de todas as nulidades. (FEUERBACH, 1973, p. 75).
\end{abstract}

Feuerbach demostra que esta discórdia principial entre deus e o homem, que a teologia afirma, é, na realidade, a oposição entre o homem e sua própria essência. Para ele, a segregação de deus do homem é nada mais do que uma obra da inteligência, do intelecto, pois deus per se, sem corpo, "sem carne e sangue", sem as necessidades e os impulsos sensíveis, é um puro abstractum, um puro res rationis, isto é, uma essência puramente pensada. A aceitação de um deus incorporal, impessoal, infinito corrobora, pois, apenas a infinitude do poder do pensamento. Deus é, então, a manifestação do pensar ou o pensar mesmo, que se transforma numa essência universal, infinita ou num êtré suprême, absoluto. Trata-se aqui não de duas essências ou substâncias, deus e o pensamento, mas apenas da unidade do pensar consigo mesmo, com sua própria essência, pois que deus é aquela representação (Vorstellung) ou ideia (Idee), que

\begin{tabular}{|l|l|l|l|l|}
\hline Qenista Dialectus & Ano 5 & n. 12 & Janeiro - Julho 2018 & p. 8-35 \\
\hline
\end{tabular}




\section{A FUNDAMENTAC̄̃̃O SUBJETIVA E SOCIAL DA RELIGIÃ̃O...}

Eduardo F. Chagas

expressa a essência do entendimento humano contemplada como totalidade (Totalität) e perfeição (Vollkommenheit) de si mesma. Mas a essência do pensamento, idêntica com deus, colocada como uma essência sem antropomorfismo e afeto, não satisfaz à religião cristã, porque sua determinação distintiva para deus é a auto-afirmação da essência sensitiva, emocional, do homem. No âmbito da religião cristã, o homem deseja, pois, "que deus seja, mas precisamente porque ele quer que seu deus seja uma essência para ele, uma essência humana.” (FEUERBACH, 1973, p. 90). Deus é para ela a perfeição moral, o ser absolutamente sagrado, por assim dizer a essência moral do homem, mas venerada como uma essência sobrehumana e sobrenatural; ela põe no lugar do deus visível, sensível, um invisível, não-sensível. Por meio dela, o homem é estranho à sua própria essência, já que ele se experimenta nela não como um ser sensível-temporal, social, mas puro, atemporal e isolado.

Assim considerado, deus e todos os conteúdos transcendentes são produtos fantásticos da vontade humana, projeções humanas. Deste ponto de homem acredita em um deus, que é nada mais do que expressão de sua sensível, emotiva. ${ }^{3}$ Disso não segue, todavia, que o homem se reduza à pura, fora do espírito e do querer. Para Feuerbach, somente três essências amor (Liebe), o espírito (mens, Geist) e a vontade (volutas, Wille) - podem inteiramente o homem, porque elas trazem em si a totalidade de suas Esta totalidade anuncia a religião cristã apenas indireta e invertidamente, na que ela, como patenteado, faz inconscientemente das determinações humanas qualidades universais, abstratas de deus. Para ela, deus está, na verdade, conteúdo, mas abstraído da vida real, pois "quanto mais vazia for a vida, tanto rico, mais concreto será o deus. O esvaziamento do mundo real e o divindade é um único e mesmo ato." (FEUERBACH, 1973, p. 148). Porque a

\footnotetext{
Cf. para isso outrossim o escrito Preleções sobre a Essência da Religião (Vorlesungen über das Wesen der Religion) (1848), no qual Feuerbach afirma: "Na religião, o homem não satisfaz nenhum outro ser; ele satisfaz nela sua própria essência." Ou ainda: "Os deuses de um povo vão até onde seus sentidos também alcançam." (FEUERBACH, 1967, p. 88-89). Em A Essência do Cristianismo (Das Wesen des Christentums), ele (FEUERBACH, L. Das Wesen des Christentums. Op. cit.) escreve também: "Se as plantas tivessem olhos, gosto e juízo - cada planta iria escolher a sua flor como a mais bela, porque o seu gosto não iria além da sua capacidade essencial produtiva." Esta posição crítica de Feuerbach à imagem de deus filia-se àquela posição do pré-socrático Xenófanes, para quem deus (théos) é também uma obra do homem. Nos Fragmentos 15 e 16 diz Xenófanes: "Os egípcios dizem que os deuses têm nariz chato e são negros, os trácios, que eles têm olhos verdes e cabelos ruivos." Ou mais preciso ainda: "Mas se mãos tivessem os bois, os cavalos e os leões pudessem com as mãos desenhar e criar obras como os homens, os cavalos semelhantes aos cavalos, os bois semelhantes aos bois, desenhariam as formas dos deuses e os corpos fariam tais quais eles próprios têm." (XENOPHANES, 1968, p. 121).
}

\begin{tabular}{|l|l|l|l|l|}
\hline Qevista Qialectus & Ano 5 & n. 12 & Janeiro - Julho 2018 & p. 8-35 \\
\hline
\end{tabular}




\section{A FUNDAMENTACÃO SUBJETIVA E SOCIAL DA RELIGIÃO...}

Eduardo F. Chagas

cristã vê em deus a satisfação das necessidades internas do homem, ela retira, vida dos limites postos pela natureza e, com isto, reduz as satisfações reais do uma satisfação puramente ilusória; ela se abstrai da natureza e se refere ao tudo o que nele é apenas em sua aparência, não em sua essência, porque constitui para ela a essência.

Essa ideia, que deriva da essência humana a essência de deus, tem Feuerbach desenvolvido não só em A Essência do Cristianismo, mas também em alguns pequenos escritos, como A Essência da Fé no sentido de Lutero (Das Wesen des Glaubens im Sinne Luthers), A Diferença entre a Divinização pagã e cristã do Homem (Der Unterchied der heidnischen und christlichen Menschenvergötterung), História da Filosofia Moderna (Geschichte der neueren Philosophie) e Princípios da Filosofia do Futuro (Grundsätze der Philosophie der Zukunft). Em A Essência do Cristianismo, Feuerbach, fiel ao seu objeto de estudo, tem abstraído da natureza, porque no Cristianismo deus "existe" sem a natureza; o Cristianismo mesmo ignora a natureza, ou seja, põe no cume um deus antinatural, que através de seu puro querer cria e governa o mundo. Este escrito de Feuerbach tem por objeto deus apenas como um ser moral, no qual a essência moral do homem se põe, nada mais do que, absolutamente, isto é, manifesta sua essência divinizada e objetivada espiritualmente. Por isto, para Feuerbach, a teologia cristã é, como visto, em seu fundamento e resultado final antropologia. O Cristianismo, que se abstrai da natureza, adora não o sol, a lua, as estrelas, o fogo, o ar, mas as forças (vontade, entendimento, consciência etc.) que fundamentam a essência humana como essência divina em contraste com a natureza, por isto Feuerbach não tem falado, em A Essência do Cristianismo, da natureza, mas meramente da essência do homem como objeto da religião, como princípio subjetivo ou como conteúdo verdadeiro da representação de deus. Mais tarde, nas Preleções sobre a Essência da Religião (Vorlesungen über das Wesen der Religion), o próprio Feuerbach confessa que o descuido do momento da natureza como objeto da religião e do sentimento de dependência (Abhängigkeitsgefühls) como base da religião representa na Essência do Cristianismo uma grande lacuna e tem dado, neste sentido, mal-entendidos a respeito de sua filosofia.

\section{A CRÍTICA DA RELIGIÃO COMO CRÍTICA DA REALIDADE SOCIAL NO PENSAMENTO DE KARL MARX}

\begin{tabular}{|l|l|l|l|l|}
\hline Q Ronista Dialectus & Ano 5 & n. 12 & Janeiro - Julho 2018 & p. 8-35 \\
\hline
\end{tabular}


Marx não desenvolveu de maneira detida e sistemática sua crítica à religião, considerando até um problema já amplamente trabalhado por Feuerbach ${ }^{4}$, embora tenha dado diversos destaques à relação entre a religião e o capitalismo, tal como fê-lo, meio século depois, Max Weber na associação do protestantismo com o capitalismo em sua obra Ética Protestante e o Espírito do Capitalismo..$^{5}$ No entanto, pode-se dizer que Marx esboçou diferentes concepções acerca da religião, tratando dela, tal como da ética, da filosofia, da família, da política, do direito, do Estado etc., como um produto das ideias, das representações teóricas, da consciência utópica, como produção espiritual de um povo, como uma forma social de consciência, pertencente à esfera da superestrutura ideológica $^{6}$ (como ideologia religiosa), condicionada, pois, pela produção material, pela estrutura econômica, a base da sociedade, e pelas relações sociais correspondentes. Como Marx diz no Prefácio (Vorwort) à Para a Crítica da Economia Política (Zur Kritik der politischen Ökonomie) (1859):

A totalidade das relações de produção constitui a estrutura econômica da
sociedade, a base real sobre a qual se eleva uma superestrutura jurídica e
política e à qual correspondem determinadas formas de consciência social. O
modo de produção da vida material condiciona em geral o processo da vida
social, política e intelectual. Não é a consciência dos homens que determina o
seu ser; mas, ao contrário, é o seu ser social que determina a sua consciência.
[...] Com a transformação da base econômica altera-se, mais ou menos
rapidamente, toda a imensa superestrutura. Na consideração de tais
transformações é necessário sempre distinguir entre a transformação material
- que se pode comprovar de maneira cientificamente rigorosa - das

4 Cf MARX, K. Zur Kritik der hegelschen Rechtsphilosophie. Einleitung. (Para a Crítica da Filosofia Hegeliana do Direito. Introdução) (1843-1844) In: Marx/Engels, Werke (MEGA). Berlin: Dietz Verlag, 1957, v. 1, p. 378, na qual Marx diz: "Para a Alemanha, a crítica da religião está, no essencial, terminada".

5 Acerca disto, cf. LÖWY, Michael. “Marxismo y Religión: opio del Pueblo?”. In: La Teoria Marxista Hoy - Problemas y Perspectivas. Buenos Aires: Editora Clacso, 2006, p. 281-296. Já Walter Benjamin vê, de acordo com o meu parecer, diferentemente de Max Weber, o capitalismo não só condicionado pela religião, mas também como um fenômeno essencialmente religioso. Walter Benjamin aponta quatro traços que podem ser identificados na estrutura religiosa do capitalismo: 1) primeiro, o culto, ou seja, o capitalismo como uma religião cultual, pois ele se expressa nos ornamentos das células bancárias; no capitalismo, as coisas só adquirem significado na relação imediata com o culto, com os ornamentos do papel-moeda, com a adoração às coisas, ao dinheiro etc.; 2) segundo, a duração permanente do culto; o capitalismo é a celebração sem trégua de um culto constante à ostentação; 3 ) terceiro, a culpabilidade; o capitalismo como uma condição sem saída que tem que ser aguentado pelo homem até o fim, levando-o ao estado de esfacelamento, de desespero, de angústia; e 4) quarto, o ocultamento; nessa religião capitalista, Deus é ocultado, para ser invocada a culpa como destino do homem, culpa essa que é martelada constantemente em sua consciência. Sobre isto, cf. BENJAMIN, Walter. O Capitalismo como Religião. São Paulo: Boitempo Editorial, 2013, p.21-51.

6 Sobre a religião como superestrutura em Marx, cf. HECKTHEUER, Fábio Rychecki. A Religião em Feuerbach e Marx: perspectivas para uma Releitura. Dissertação. Pelotas: PUC, 1993, p. 70-106.

\begin{tabular}{|l|l|l|l|l|}
\hline Q Ponista Dialectus & Ano 5 & n. 12 & Janeiro - Julho 2018 & p. 8-35 \\
\hline
\end{tabular}




\section{A FUNDAMENTAC̄̃̃O SUBJETIVA E SOCIAL DA RELIGIÃO... \\ Eduardo F. Chagas}

condições econômicas de produção e as formas jurídicas, políticas, religiosas, artísticas ou filosóficas, em resumo, as formas ideológicas.

Mas, para Marx, como materialista e ateu convicto, a religião ocupa uma posição especial na superestrutura, diferentemente das demais formas ideológicas, a saber, a política, a social e a cultural, na medida em que ela, não na sua dimensão privada, exercida por um indivíduo particular, que só a ele diz respeito, mas na sua dimensão social e política enquanto expressão de alheamento do homem de seu mundo real e de conformação social com esse mundo, corroborando para a "perpetuação" de uma dada sociedade, deve ser suprimida positivamente. Suprimir positivamente a religião significa, de acordo com o meu parecer, negar a religião não na esfera privada, enquanto prática individual, mas na esfera pública, a função social dela. O foco de Marx é a crítica ao revestimento religioso, ou seja, a presença da religião, por exemplo, na sociedade civil (como na religião, em que há uma cisão entre a esfera terrena e a esfera celeste, a sociedade civil enquanto esfera do aquém, privada, profana, está em oposição à esfera do além, do "sagrado", do Estado), no Estado (como um universal sagrado, eterno, uma totalidade, um guardião protetor), no capital (a fé no capital, visto como um grande deus, o deus-capital, o verdadeiro deus, o único deus real e vivo, o deus implacável, o deus sinistro, que faz e desfaz, que cria e destrói, que pode ser conhecido, visto, tocado, cheirado, provado, um deus todo-poderoso, ilimitado, eterno, internacional, universal, presente em todos os locais, manifestado sob diferentes formas), no "milagre" das tecnologias, na mercadoria (as transformações, as encarnações de uma mercadoria em outras), no reino do dinheiro, do ouro (o dinheiro como objeto adorado, venerado, como "a alma" do capitalismo, que move o universo e é mercadoria milagrosa que contém em si outras mercadorias), nos "princípios sagrados, eternos" do trabalho (o trabalho como atividade sagrada, da qual deus compensa) ${ }^{8}$, como objetos de adoração, que, embora profanos, laicos, se revestem de religiosidade, se apresentam de forma religiosa, ocultando seus conteúdos.

Qual o significado, todavia, da religião em geral para Marx? Penso que, do ponto de vista de Marx, a religião se expressa de cinco maneiras: 1. como uma expressão às avessa, como um reflexo invertido da totalidade das condições inumanas

7 MARX, K. Kritik der politischen Ökonomie. In: Marx/Engels, Werke (MEGA). Berlin: Dietz Verlag, 1983, v. 13, p. 8-9.

${ }^{8}$ Cf. LAFRAGUE, Paul. A Religião do Capital. Rio de Janeiro: Editora Achiamé, s/d., p. 16, 18, 33 e 68-69.

\begin{tabular}{|l|l|l|l|l|}
\hline Qevista Dialectus & Ano 5 & n. 12 & Janeiro - Julho 2018 & p. 8-35 \\
\hline
\end{tabular}




\section{A FUNDAMENTACÃO SUBJETIVA E SOCIAL DA RELIGIÃO...}

Eduardo F. Chagas

em que se encontra o homem na sociedade capitalista e, por isto, 2. como uma contestação, uma recusa ou como um protesto indireto contra a dor, o sofrimento, o desamparo real, contra uma condição insatisfatória imposta ao homem; 3. mas como um protesto impotente, como uma impotência para combater essa condição insatisfatória, como uma barreira, um obstáculo que impede ao homem a tomada de consciência de sua situação inumana, para conduzir, na prática, uma transformação da sociedade, marcada pela propriedade privada à custa da exploração do homem pelo homem; 4. como uma esperança na salvação não neste mundo, mas no paraíso, no além, como uma ilusão de um outro mundo, de uma felicidade ilusória, de um mundo imaginário, celestial, oposto ao mundo real, de privações, de miséria, ou seja, de um mundo melhor, perfeito, como o céu, o paraíso, no qual o homem se vê livre de uma vida insuportável, de sua situação inumana, miserável, quer dizer, uma ilusão necessária para suportar as dores reais advindas do mundo do capital de exploração e desumanização, fornecendo, pois, ao homem a religião 5. como uma explicação não verdadeira, mas fantasiosa, mistificada da realidade, levando-o à passividade, à consolação com a esperança da recompensa celeste, ao conformismo e à resignação, que corrobora com o status quo e legitima as condições inumanas existentes.

A crítica à religião é, para Marx, a premissa, a condição preliminar, "o pressuposto de toda a crítica"9, pois, ao criticarmo-la, estamos, na verdade, também criticando a realidade, da qual ela nasce e que é o fundamento dela, a raiz social, a fonte do entontecimento religioso. A religião não é autônoma, existente para si, mas reflexo fantástico das potências exteriores, terrestres, que adquirem formas "supraterrestres" e passam a dominar o homem; ela é, pois, reflexo deformado, expressão distorcida, consciência invertida (Deus fez o homem, e não o homem quem fez Deus) de um mundo distorcido, invertido (o Estado como fundador da sociedade civil, e não a sociedade civil como formadora do Estado), do mundo invertido do capital, no qual o sujeito trabalhador aparece não como sujeito, mas como dependente do capital, e o capital, que é depende do trabalho, aparece como sujeito). A religião não é a base, mas expressão do mundo estranhado; e, se o homem está dividido na religião entre seu ser genérico, seu ser universal (Deus), e seu ser singular, individual (o homem concreto), é porque o mesmo homem já está, no mundo real, fragmentado, mutilado entre sua vida universal, abstrata, no Estado, e sua vida real, individual, na sociedade civil-burguesa.

${ }^{9}$ MARX, K. Zur Kritik der hegelschen Rechtsphilosophie Einleitung. Op. cit., p. 378.

\begin{tabular}{|c|c|c|c|c|}
\hline Qevista Dialectus & Ano 5 & n. 12 & Janeiro - Julho 2018 & p. 8-35 \\
\hline
\end{tabular}




\title{
A FUNDAMENTAC̄̃̃O SUBJETIVA E SOCIAL DA RELIGIÃ̃O...
} Eduardo F. Chagas

A religião é um fenômeno social, como uma imagem do mundo invertido, das reais contradições da sociedade, por exemplo, das contradições da realidade do capital, e não é enfrentando diretamente a religião que a desvelaremos, como fê-lo Feuerbach, mas desvelando as suas raízes sociais, as contradições do real, que revelaremos o seu segredo. Por isso, Marx critica, precisamente, Feuerbach, porque este inverteu a ordem da crítica, tomando como tarefa fundamental revelar o segredo da religião, sem revelar a sua base material, o seu fundamento, que é a sociedade concreta, que engendra a religião. Para compreender a religião, Marx não passa do "reino de Deus" para o "reino dos homens", não desce do céu à terra, mas parte da terra, das coisas terrestres, reais, para compreender o céu, as coisas celestes. Como diz Marx na $I V$ Tese sobre Feuerbach (Thesen über Feuerbach) (1845-46):

\begin{abstract}
Feuerbach parte do fato do auto-estranhamento religioso, da duplicação do mundo num mundo religioso imaginário e num mundo real. Seu trabalho consiste em dissolver o mundo religioso em seu fundamento terreno. Ele não vê que, depois de completado esse trabalho, o principal ainda resta por fazer. Mas o fato de que este fundamento se eleve de si mesmo e se fixe nas nuvens como um reino autônomo, só pode ser explicado pelo auto-dilaceramento e pela auto-contradição desse fundamento terreno. Este deve, pois, ser primeiramente compreendido em sua contradição e depois revolucionário praticamente, pela eliminação da contradição. Assim, por exemplo, uma vez descoberto que a família terrestre é o segredo da sagrada família, é a primeira que deve ser criticada na teoria e revolucionada na prática. ${ }^{10}$
\end{abstract}

Precisamente, em A Ideologia Alemã (Die deutsche Ideologie) (1845-46), Marx, e também Engels, mantém, de modo explícito, uma postura anti-especulativa, opondo-se às ideias tomadas como abstratas, autônomas, pelos neo-hegelianos (Feuerbach, Bauer e Stirner). Marx, e também Engels, enfatiza que as ideias pertencem a uma época, e não uma época a uma ideia determinada, ou seja, que não se explica a práxis a partir das ideias, mas se explica as formações ideológicas a partir da práxis material. Ao contrário do pensamento sem pressuposto, eles partem de pressupostos reais e inelimináveis, da produção material da vida, dos meios para satisfazer as necessidades vitais (comer, beber, ter habitação, vestir-se), com os quais "a produção das idéias, das representações da consciência está [...] imediatamente entrelaçada". ${ }^{11}$ Portanto, embora as ideias, as representações, sejam produzidas pelos homens, elas, e

10 MARX, K. Thesen über Feuerbach. In: Marx/Engels, Werke (MEGA). Berlin: Dietz Verlag, 1958, v. 3, p. 534 .

11 MARX, K e ENGELS, F. Die deutsche Ideologie. In: Marx/Engels, Werke (MEGA). Berlin: Dietz Verlag, 1958, v. 3, p. 26.

\begin{tabular}{|c|c|c|c|c|}
\hline Qevista Dialectus & Ano 5 & n. 12 & Janeiro - Julho 2018 & p. $8-35$ \\
\hline
\end{tabular}


todas as formas de ideações, como a religião, a moral, a filosofia e qualquer outra ideologia, não são autônomas, independentes, desligadas das bases materiais e temporais, dos fatos, desprovidas de pressupostos, incondicionadas, auto-engendradas, mas são expressões ideais das circunstâncias reais, das condições materiais de existência, extraídas do mundo real, isto é, têm como raiz, como fonte primária, a produção e o intercâmbio material da vida social-humana.

Nesse sentido, Marx acredita que Feuerbach não resolveu, por exemplo, o problema fundamental da religião, porque ignorou a base social dela, não percebendo que ela não é autônoma, abstrata, atemporal, mas um produto social, que pertence a uma determinada forma social e que passa por transformações em diferentes períodos históricos ${ }^{12}$. Isso Marx deixa claro na VII "Tese ad Feuerbach": "Feuerbach não vê que o próprio 'espírito religioso' é um produto social e que o indivíduo abstrato, que ele analisa, pertence na realidade a uma forma social determinada"13. Marx defende que o homem produz a religião ${ }^{14}$, sonha com um mundo fantasioso, projeta sua essência num ser superior, porque ele não vê, na vida real da sociedade, as condições para o desenvolvimento de sua humanidade. A religião é "a realização fantástica da essência humana, porque a essência humana não possui verdadeira efetividade." ${ }^{15}$ Portanto, para superar positivamente a religião, o seu estranhamento, não é suficiente revelar o seu segredo, combatê-la subjetivamente, mas é necessário transformar as condições reais de vida que favorecem o surgimento e o desenvolvimento da religião, das "quimeras celestes".

12 Cf. MARX, K. ENGelS, F., in: Manifest der Kommunistischen Partei (Manifesto do Partido Comunista) (1848), in: Marx/Engels, Werke (MEGA), Berlin: Dietz Verlag, 1959, v. 4 p. 480: "Será necessária grande perspicácia para compreender que as ideias, as concepções e os conceitos dos homens, numa palavra, a sua consciência, mudam com as alterações introduzidas nas suas condições de vida, nas suas relações sociais, na sua existência social?" "Que demonstra a história das ideias senão que a produção intelectual se transforma com a produção material?".

13 MARX, K. Thesen über Feuerbach. Op. cit., p. 535.

14 In: Zur Kritik der hegelschen Rechtsphilosophie. Einleitung. Op. cit., p. 378, Marx enfatiza: "O fundamento da crítica irreligiosa é: foi o homem quem fez a religião; a religião não fez o homem." Cf. também o Prefácio da Doktordissertation (Tese de Doutorado), Differenz der demokritischen und epikureischen Naturphilosophie (Diferença entre as Filosofias da Natureza em Demócrito e Epicuro) (1841) in: Marx/Engels, Werke (MEGA), Ergänzungsband, Erster Teil, Berlin: Dietz Verlag, 1968, p. 262, no qual Marx, fazendo alusão à tragédia "Prometeu Agrilhoado", de Ésquilo, demonstra que "A profissão de fé de Prometeu: 'Eu odeio todos os deuses; eles são meus subordinados e deles sofro um tratamento iníquo', é a sua própria profissão de fé, a sua própria máxima contra todos os deuses do Céu e da Terra, que não reconhecem como divindade suprema a autoconsciência humana." Esse antropomorfismo da religião pode ser ilustrado com uma frase de Epicuro, citada aqui por Marx: “'Ímpio não é aquele que acaba com os deuses da multidão, mas aquele que atribui aos deuses as representações da multidão.’”

15 MARX, K. Zur Kritik der hegelschen Rechtsphilosophie. Einleitung. Op. cit., p. 378.

\begin{tabular}{|l|l|l|l|l|}
\hline Qevista Zialectus & Ano 5 & n. 12 & Janeiro - Julho 2018 & p. 8-35 \\
\hline
\end{tabular}


Na Crítica da Filosofia do Direito de Hegel - Introdução, (Zur Kritik der hegelschen Rechtsphilosophie. Einleitung) (1843-44), Marx enfatiza também que é o homem quem cria a religião e que a realidade é o fundamento dela, e não o contrário:

\begin{abstract}
Mas o homem não é um ser abstrato, acocorado fora do mundo. O homem é o mundo do homem, o Estado, a sociedade. Este Estado e esta sociedade produzem a religião, uma consciência invertida do mundo, porque eles são um mundo invertido. A religião é a teoria geral deste mundo, o seu compêndio enciclopédico, a sua lógica em forma popular, o seu point d'honneur ('ponto de honra') espiritual, o seu entusiasmo, a sua sanção moral, o seu complemento solene, a sua fundamental razão de consolação e de justificação. Ela é a realização fantástica da essência humana, porque a essência humana não possui realidade verdadeira. Por conseguinte, a luta contra a religião é, indiretamente, a luta contra aquele mundo, cujo aroma espiritual é a religião. ${ }^{16}$
\end{abstract}

Em A Questão Judaica (Zur Judenfrage) (1844) Marx mostra que não só Feuerbach, mas também Bruno Bauer tratam do problema da emancipação, da autonomia e da liberdade só a partir da crítica à religião, ao Estado cristão. Contrário a essa posição, Marx substitui a crítica ao Estado teológico, cristão, pela crítica ao Estado profano, político, pois que a questão da emancipação humana não é apenas uma disputa teológica, um problema estritamente religioso, nem político-burguês, como considera Bauer, mas principalmente humano-social. Segundo Bauer:

O Estado cristão conhece apenas privilégios. O judeu, neste Estado, possui o privilégio de ser judeu. O Estado cristão, em razão de sua natureza, não pode emancipar o judeu; mas o judeu, em razão de sua essência, não pode ser emancipado. Enquanto o Estado permanecer cristão e o judeu continuar a ser judeu, são igualmente incapazes, aquele de conferir e este de receber a emancipação. ${ }^{17}$

Bauer concentra sua atenção na emancipação política exclusivamente e, por isso, se contenta em fazer a crítica à religião, ao Estado religioso. Para lograr tal intento, pede ele a todos os religiosos e ao Estado a abolição da religião, por ser um fator de segregação humana. Tanto os cristãos como os judeus devem superar o preceito teológico, que Bauer considera contrário à razão e à natureza humana. Por isso, o

16 MARX, K. Zur Kritik der hegelschen Rechtsphilosophie. Einleitung. Op. cit., p. 378. Cf. também a VI "Tese ad Feuerbach", p. 534, na qual Marx deixa claro sua distinção em relação a Feuerbach: "Feuerbach dissolve a essência religiosa na essência humana. Mas a essência humana não é uma abstração inerente ao indivíduo isolado. Na sua efetividade, é o conjunto das relações sociais.”

17 MARX, K. Zur Judenfrage. In: Marx/Engels, Werke (MEGA), Berlin: Dietz Verlag, 1957, v. 1, p. 347-48.

\begin{tabular}{|l|l|l|l|l|}
\hline Qovista Dialectus & Ano 5 & n. 12 & Janeiro - Julho 2018 & p. 8-35 \\
\hline
\end{tabular}




\section{A FUNDAMENTAC̄̃̃O SUBJETIVA E SOCIAL DA RELIGIÃO... \\ Eduardo F. Chagas}

Estado teológico é, para ele, menos Estado que o Estado político, profano, já que a presença da religião e de seus critérios na esfera pública impedem a formulação de um bem comum, fundado na comunidade de homens livres, na igualdade de direitos e no desfrute da liberdade. Assim como o homem autêntico, racional e livre é aquele que supera o preceito religioso, assim também o Estado legítimo é o Estado político, laico, anti-religioso, que está voltado unicamente para a realização da liberdade segundo a razão.

Nesse sentido, a suplantação da religião é, para Bauer, o pressuposto da emancipação política, dado que o judeu deixará de ser judeu quando o Estado não atingir mais o cumprimento de uma dada religião e abolir, por conseguinte, todos os privilégios religiosos, incluindo a preponderância de uma igreja privilegiada. Com efeito, Bauer almeja que o judeu abdique ao judaísmo, que o cristão deixe o Cristianismo e que o homem em geral renuncie à religião, para que possam se emancipar politicamente como cidadãos. Tendo em vista a interpretação segundo a qual o Estado que pressupõe a religião não é ainda um Estado verdadeiro, efetivo, uma associação de homens livres, mas uma associação de crentes ${ }^{18}$, Bauer corrobora então a ideia de que a supressão da religião é condition sine qua non para a realização da liberdade e da autonomia humanas, que se efetiva no Estado político. Ao contrário dessa posição, Marx diz que tal questão é unilateral, já que não é necessário que o indivíduo renuncie à religião para lograr sua liberdade no plano político. É evidente que a emancipação política constitui um colossal avanço, mas ela não é, na verdade, a forma última da emancipação humana enquanto tal. Por isso, frisa Marx:

Devido ao fato de não formular a questão a este nível, Bauer cai em contradições. Põe condições que não são fundadas na natureza mesma da emancipação política. [...] Quando Bauer diz aos adversários da emancipação judaica: 'O seu erro foi somente supor que o Estado cristão era o único verdadeiro e que não tinha de submeter-se à crítica dirigida ao judaísmo' vemos o equívoco de Bauer no fato de só submeter à critica o 'Estado cristão', e não o 'Estado como tal'; de não analisar a relação entre emancipação política e emancipação humana e, portanto, de colocar situações

${ }^{18}$ Sobre a religião como fundamento, base, do Estado, cf. também MARX, K, "Nr. 179 der Kölnischen Zeitung" ("Editorial do $N^{o} 179$ da 'Gazeta de Colônia"') (1842), in: Marx/Engels, Werke (MEGA), Berlin: Dietz Verlag, 1957, v. 1, p. 94 e 101: “um Estado 'cristão', que tem por fim, em vez de uma associação livre de homens morais, uma associação de crentes, em vez da realização da liberdade, a realização do dogma. Todos os nossos Estados europeus têm o cristianismo como base". Precisamente, "O Estado verdadeiramente religioso é o Estado teocrático; o soberano de tais Estados deve ou, como no judaísmo, ser o Deus da religião, o Jeová, ou então, como no Tibete, ser o representante de Deus, o Dalai Lama".

\begin{tabular}{|l|l|l|l|l|}
\hline Q Rovista Qialectus & Ano 5 & n. 12 & Janeiro - Julho 2018 & p. 8-35 \\
\hline
\end{tabular}




\section{A FUNDAMENTAC̄̃̃O SUBJETIVA E SOCIAL DA RELIGIÃO... \\ Eduardo F. Chagas}

que só se explicam pela confusão, devido às lacunas da crítica, entre emancipação política e emancipação geral da humanidade. ${ }^{19}$

Marx não parte, como Bauer, da relação entre emancipação política e religião, mas sim entre emancipação política e emancipação humana, tampouco busca a base da imperfeição do Estado na religião, senão no próprio Estado político. O Estado, mediado pela política representativa moderna, democrático-burguesa, pode desprenderse do constrangimento religioso, sem que o homem seja realmente livre. Por exemplo, o Estado político moderno suprime, de forma política-burguesa, ou seja, abstrato-formal, a propriedade privada, mas tal supressão pressupõe, ao contrário, a existência dela no mundo real. Em princípio, ele não admite nenhuma distinção de fortuna, de nascimento, de posição social, de instrução ou de profissão, porque proclama a emancipação igualitária do indivíduo perante aos direitos humano-universais, à democracia burguesa e à soberania nacional. Mas, na verdade, longe de suprimir as sobreditas distinções, diferenças e desigualdades, o Estado político só existe na medida em que as pressupõe. Por isso, esse Estado atinge sua universalidade de forma abstrata, isto é, sobre esses elementos particulares, sobre essas diferenças sociais, configurando-se, portanto, como explicitação da vida genérica do homem em oposição à sua vida real.

No Estado político-moderno, são declarados os direitos do homem, como a liberdade, a propriedade, a igualdade e a segurança. Contudo, essa liberdade, concebida como direito do homem, não se objetiva nas relações sociais, senão no direito do indivíduo segregado, fechado em si mesmo. A objetivação prática desse direito constitui, por isso, o direito à propriedade privada. $\mathrm{O}$ direito humano à propriedade privada é, por sua vez, o direito de usufruir dos bens e rendimentos, sem conceder devida atenção aos outros homens. Desse modo, o direito à igualdade torna-se meramente uma subscrição dos dois anteriores mencionados, quer dizer, a igualdade política não tem correspondência na igualdade real-social. Por fim, o direito à segurança consiste na garantia outorgada pela sociedade a cada um de seus membros para a preservação de sua pessoa, de seus direitos e de sua propriedade. Assim, nenhum desses supostos direitos do homem transcende a propriedade privada, o egoísmo individual;

19 MARX, K. Zur Judenfrage. Op. cit., p. 350-51.

\begin{tabular}{|c|c|c|c|c|}
\hline Qevista Dialectus & Ano 5 & n. 12 & Janeiro - Julho 2018 & p. $8-35$ \\
\hline
\end{tabular}




\title{
A FUNDAMENTAC̄̃̃O SUBJETIVA E SOCIAL DA RELIGIÃO... \\ Eduardo F. Chagas
}

pelo contrário, eles estão estritamente determinados e fundamentados nos interesses pessoais, privados dos indivíduos da sociabilidade capitalista. ${ }^{20}$ Marx sublinha:

\begin{abstract}
Esse fato torna-se ainda mais misterioso quando observamos que os emancipadores políticos reduzem a cidadania, a comunidade política, a simples meio para conservar esses pretensos direitos do homem: e que, em consequência, o cidadão é declarado servidor do homem egoísta. A esfera em que o homem se comporta como ser comunitário é rebaixada a uma esfera inferior, onde ele age como ser fragmentado; e que, por fim, é o homem como burguês [...] que é considerado como homem verdadeiro e autêntico. ${ }^{21}$
\end{abstract}

Esse conflito em que o homem se vê envolto entre Estado e sociedade civil, entre vida genérica e vida real, é similar à contradição em que o burgeois - que leva uma vida retraída, privada e egoísta - se encontra com o citoyen - que participa de uma vida coletiva imaginária, despojada da vida real e dotada de uma universalidade ilusória. Essa oposição foi deixada intacta por Bauer, porquanto reduziu sua polêmica em torno do antagonismo entre religião e emancipação política. Para Marx, conquanto a emancipação política burguesa constitua um colossal avanço, ela não é ainda, como já expresso, o télos último, a plena emancipação humano-social. No Estado político, os indivíduos, sejam ou não religiosos, surgem como religiosos por causa da dicotomia entre vida individual e vida genérica, isto é, entre vida social e vida política. A religião, como elaboração espiritual da sociedade civil, aparece então como objetivação do estranhamento do homem em relação à sua genericidade, porque o homem trata a vida política despojada da vida individual, como se fosse sua verdadeira vida. Com efeito, o Estado político é a expressão máxima dessa realidade, na qual o homem acha-se corrompido, pedido de si mesmo; em síntese, sujeito aos domínios e elementos inumanos inerentes à sociabilidade do capital. Como frisa Marx:

O Estado político acabado é, pela própria essência, a vida genérica do homem em oposição a sua vida material. [...] Onde o Estado político já atingiu seu verdadeiro desenvolvimento, o homem leva, não só no plano do pensamento, da consciência, mas também no plano da realidade, uma dupla vida: uma celestial e outra terrena, a vida na comunidade política, na qual ele se considera um ser coletivo, e a vida na sociedade civil, em que atua como particular, considera os outros como meios, degrada-se a si próprio como meio e converter-se em joguete de poderes estranhos. ${ }^{22}$

20 Cf. CHAGAS, Eduardo F. "Hegel e Marx: O Caráter Formal-Abstrato dos Direitos Humanos", in: Filosofia e Direitos Humanos. Série Filosofia, v. 4, Fortaleza: Editora UFC, 2006, p. 249-68.

21 MARX, K. Zur Judenfrage. Op. cit., p. 366.

22 Ibid., p. 350-51.

\begin{tabular}{|c|c|c|c|c|}
\hline Qevista Dialectus & Ano 5 & n. 12 & Janeiro - Julho 2018 & p. $8-35$ \\
\hline
\end{tabular}


Em O Capital, (Das Kapital) (1867) Marx faz uma analogia do fetichismo religioso com o fetichismo da mercadoria: como no fetichismo da religião se oculta o homem com a verdade de Deus, assim também no fetichismo da mercadoria se oculta a realidade que está por trás da própria mercadoria, que é o trabalho, ou o produtor do trabalho; ou melhor, no fetichismo religioso, Deus aparece autônomo, independente, e o homem apenas como dependente e não como sujeito e verdade acerca da existência de Deus; e no fetichismo da mercadoria, o produto do trabalho, a mercadoria, aparece como se fosse autônomo, independente do seu produtor, e o produtor, o trabalhador, aparece como dependente e não sujeito do produto de seu próprio trabalho. Diz Marx:

\begin{abstract}
Não é mais nada que determinada relação social entre os próprios homens que aqui, para eles, assume a forma fantasmagórica de uma relação entre coisas. Por isso, para encontrar uma analogia, temos de nos deslocar à região nebulosa do mundo da religião. Aqui, os produtos do cérebro humano parecem dotados de vida própria, figuras autônomas, que mantêm relações entre si com os homens. Assim no mundo das mercadorias, acontece com os produtos da mão humana. Isso eu chamo de fetichismo, que adere aos produtos de trabalho, tão logo são produzidos como mercadorias, e que, por isso, é inseparável da produção de mercadorias. Esse caráter fetichista do mundo das mercadorias provém [...] do caráter social peculiar do trabalho que produz mercadorias [...]. O reflexo religioso do mundo real somente pode desaparecer, quando as circunstâncias cotidianas da vida prática representarem para os homens relações transparentes e racionais entre si e com a natureza. ${ }^{23}$
\end{abstract}

Um texto importante de $O$ Capital sobre o homem reificado é, precisamente, "O Caráter Fetichista da Mercadoria e o seu Segredo" (Der Fetischcharakter der Ware und sein Geheimnis). Investigando o fetichismo da mercadoria, Marx observa que o caráter "místico", "enigmático", da mercadoria não provém de seu valor de uso, mas da forma do valor, do valor de troca. Assim ele descreve o fenômeno do fetichismo da mercadoria:

O mistério da forma mercadoria consiste, portanto, simplesmente no fato de
que ela reflete aos homens as características sociais de seu próprio trabalho
como características objetivas dos produtos do trabalho mesmo, como
qualidades naturais sociais destas coisas, por isso, também reflete a relação
social dos produtores com o trabalho total como uma relação social de
objetos, que existe fora deles. Por meio desses quiproquós os produtos do
trabalho se tornam mercadorias, coisas sociais, sensíveis e suprassensíveis.
[... É Epenas a relação social determinada dos próprios homens, tomada aqui
por eles como a forma fantasmagórica de uma relação entre coisas." "Já que

23 MARX, K. Das Kapital. In: MARX/ENGELS, Werke (MEGA). Berlin: Dietz Verlag, 1962, v. 23, p. 86-87 e 94.

\begin{tabular}{|l|l|l|l|l|}
\hline Q Povista Dialectus & Ano 5 & n. 12 & Janeiro - Julho 2018 & p. 8-35 \\
\hline
\end{tabular}


os produtores somente entram em contato social mediante a troca dos produtos de seu trabalho, também as características especificamente sociais de seus trabalhos privados só aparecem dentro dessa troca. [...] Por isso, aos últimos [aos produtores], as relações sociais entre seus trabalhos privados aparecem como o que elas são, isto é, não como relações imediatamente sociais entre pessoas em seus próprios trabalhos, mas, pelo contrário, como relações reificadas entre as pessoas e relações sociais entre as coisas. ${ }^{24}$

Marx enfatiza, aqui, a condição trágica do homem no mundo do capital, pois, no processo produtivo de mercadorias, cria-se uma objetividade que anula os próprios homens. Marx destaca a presença de uma objetividade sem o homem, ou de um homem esvaziado, para o qual a realidade aparece como um mundo exterior; quer dizer, o homem desconhece o mundo, a sua própria atividade, as condições pelas quais se produzem a sua própria existência, percebendo o mundo, a existência real, como fora dele, externa e alheia a ele, e não como um produto de seu próprio trabalho, de sua própria subjetividade, tal como o religioso que produz Deus, mas não se vê como seu criador, mas como criatura externa e dominada por Deus. Marx mostra ainda que, nessas condições fetichizadas, os homens enquanto homens são abolidos e se tornam coisas vivas (de ordem mercadológica), e os produtos de seu trabalho, as mercadorias, aparecem como atributos de si mesmas, autonomizadas, dotadas de um poder sobrenatural, ocultando, assim, a sua origem, a sua fonte, isto é, o trabalho social que as fundamenta.

Já numa obra de juventude, nos Manuscritos Econômico-Filosóficos (Ökonomisch-philosophische Manuskripte) (1844), particularmente no capítulo sobre o "Dinheiro", Marx falara do fetichismo do dinheiro, comparando-o como um Deus na sociedade capitalista, pois que a propriedade privada, a posse do dinheiro e seu fetichismo aparecem como um Deus, como uma divindade, um ídolo, criado, cultuado e adorado pelo próprio sistema do capital. Marx ilustra isto com passagens literárias do Timon de Atenas, de Shakespeare:

Ouro? Amarelo, brilhante, precioso ouro? Não, deuses:

[...] Esta quantidade de ouro bastaria para transformar o preto em branco; o feio em belo; o falso em verdadeiro; o vil em nobre; o velho em jovem; o covarde em valente.

[...] Este escravo amarelo

Vai unir e dissolver religiões; bendizer amaldiçoados;

Fazer adorar a lepra lívida, dar lugar aos ladrões,

Dando-lhes títulos, genuflexões e elogios

24 Ibid., p. 86-87.

\begin{tabular}{|c|c|c|c|c|}
\hline Q Povista Dialectus & Ano 5 & n. 12 & Janeiro - Julho 2018 & p. 8-35 \\
\hline
\end{tabular}


[...] Prostituta comum de todo o gênero humano, que semeias a discórdia entre a multidão de nações. [.... $]^{25}$

E mais adiante:

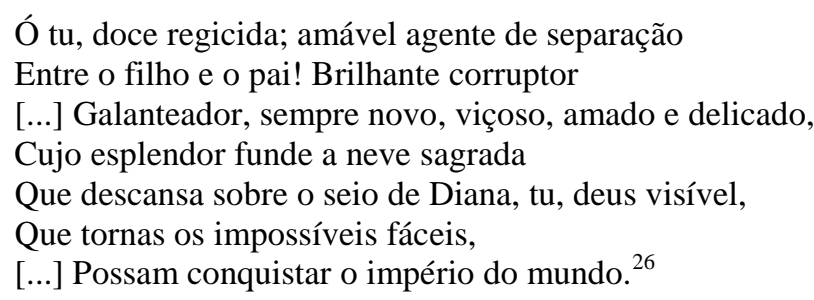

Em Shakespeare fica clara a identificação do dinheiro com uma divindade visível, como ser onipotente, poder absoluto, força divina, que pode verdadeiramente criar tudo, tornar todos os desejos humanos, todos os seus sonhos, uma realidade efetiva. O dinheiro, "o bezerro de ouro" moderno, em virtude de suas propriedades, de poder comprar tudo, de se apropriar de tudo, de ser universal e onipotente, "o sedutor" que prostitui e inverte as qualidades humanas e se converte na sociedade do capital num ser onipotente, num Deus mundano, todo poderoso, honrado e adorado.

A religião é também, como expresso, ilusão ${ }^{27}$, compensação ideal, funciona como um remédio, como um meio de evasão, de refúgio, o ópio espiritual (geiste Opium) do povo oprimido, sofrido, como uma espécie de má "aguardente espiritual" que serve para ocultar e justificar uma determinada realidade (a realidade capitalista), como uma espécie de nevoeiro, de véu sobre a irracionalidade da realidade (da produção burguesa), entontecendo, adormecendo, a consciência do homem, apaziguando a sua consciência, amparando-o, aliviando-o, consolando-o de sua miséria no mundo real, para que ele suporte e esqueça a dureza de sua realidade degradante, levando-o, pois, "gozo celeste", ao conformismo e à resignação. Como diz Marx:

A miséria religiosa é, de um lado, a expressão da miséria real e, de outro, o protesto contra a miséria real. A religião é o suspiro da criatura oprimida, o coração de um mundo sem coração, o espírito de uma situação carente de espírito. Ela é o ópio do povo. ${ }^{28}$

25 MARX, K. Geld. In: Ökonomisch-philosophische Manuskripte aus dem Jahre 1844. Marx/Engels, Werke (MEGA), Bd. 40. Dietz Verlag, Berlin, 1990, p. 563-64.

26 Ibid., p. 564.

27 Em Totem e Tabu (Totem und tabu) (1913), O Futuro de uma Ilusão (Die Zukunft einer Illusion) (1927) e Moisés e o Monoteísmo (Der Mann Moses und Die Monotheistiche Relgion) (1939), Freud interpreta também a religião como ilusão, como ilusão consoladora face à dureza da vida, como "um. sistema de ilusões plenas de desejo juntamente com um repúdio da realidade".

28 MARX, K. Zur Kritik der hegelschen Rechtsphilosophie. Einleitung. Op. cit., p. 378.

\begin{tabular}{|l|l|l|l|l|}
\hline Q Rovista Qialectus & Ano 5 & n. 12 & Janeiro - Julho 2018 & p. 8-35 \\
\hline
\end{tabular}


Marx acredita que, para libertar o homem da religião, de suas ilusões religiosas, é necessário primeiro libertá-lo do tipo de vida que o leva a ansiar pela religião, ou seja, é preciso mudar o mundo em que o homem precisa de ilusões. Livrando-se das "flores imaginárias", pode-se colher as "flores vivas". Neste sentido, é fundamental não combater o efeito, mas a causa da religião, que é a estrutura social, política e econômica da sociedade capitalista.

Enfatiza Marx:

Assim, a tarefa da história, depois que o mundo do além da verdade se desvaneceu, consiste em estabelecer a verdade deste mundo. É primeira tarefa da filosofia, que está a serviço da história, desmascarar o auto estranhamento humano em suas formas não santificadas, depois que ela foi desmascarada na forma sagrada. Com isto, a crítica do céu se converte na crítica da terra, a crítica da religião na crítica do direito, a crítica da teologia na crítica da política. ${ }^{29}$

Afirma Marx ainda:

A crítica da religião leva à doutrina de que o homem é o ser supremo para o homem e, consequentemente, ao imperativo categórico de derrubar todas as relações, nas quais o homem é um ser humilhado, escravizado, abandonado e desprezível. ${ }^{30}$

Portanto, a religião, o mundo fantástico dos deuses, existe, porque existe um mundo irracional e injusto ao homem. Ela não é fruto de uma revelação sobrenatural, não é produto da ignorância, nem da invenção de impostores, de profetas, teólogos ou líderes, nem de uma conspiração clerical, mas produto do homem oprimido, explorado, que busca alívio, abrandamento, consolo na religião, no seu universo imaginário, acerca de suas dores e seus sofrimentos. Assim, a religião e suas ilusões não desaparecerão, enquanto não se eliminarem as condições que as criam; e sem a superação dessas condições, a felicidade será alcançada só no outro mundo e o paraíso será sempre um paraíso celeste, e não "um paraíso real”, na terra, num futuro histórico. Não se trata aqui de uma posição dogmática e inflexível de Marx a favor de uma luta decidida contra toda religião, ou de uma defesa da abolição do sentimento religioso pela força, pela violência, ou da pretensão de transformar, por “ordem superior”, por decreto, os crentes

29 Ibid., p. 379.

30 Ibid., p. 385 .

\begin{tabular}{|l|l|l|l|l|}
\hline Q Povista Dialectus & Ano 5 & n. 12 & Janeiro - Julho 2018 & p. 8-35 \\
\hline
\end{tabular}




\section{A FUNDAMENTAC̄̃̃O SUBJETIVA E SOCIAL DA RELIGIÃ̃O...}

Eduardo F. Chagas

em ateus, como queriam, de forma sectária, os blanquistas, os anarquistas, durante a Comuna de Paris, e alguns bolchevistas durante a República Socialista Soviética, e estabelecer uma sociedade ateia. Não há no pensamento de Marx o ateísmo como um artigo de fé obrigatório, menos ainda "um policiamento espiritual", como a defesa do desdém, da injúria, do preconceito, da intolerância, da proibição ou perseguição à religião em geral. Na verdade, há o entendimento de que a religião deve ser uma questão privada ${ }^{31}$ em relação ao Estado, ao espaço público e a cada indivíduo, que deve ser livre para crer ou não, pois deve haver liberdade de consciência e de crença para todos, bem como tolerância e respeito, que devem ser universais, às pessoas que são crentes. ${ }^{32}$ A ênfase que se deu aqui foi, por um lado, uma crítica a uma dada forma de sociedade e ao seu ordenamento político, o Estado, que se apresentam, embora laicos, de forma religiosa, ocultando suas verdadeiras funções de exploração e opressão, e, por outro lado, uma "negação específica" da religião, a saber, a negação da religião quando ela é utilizada em prejuízo ao ser humano; a negação dela enquanto obscurantismo, como superstição, idolatria, misticismo, como narcótico que mantém o indivíduo paralisado, acomodado no seu lugar, a serviço do capitalismo, que o explora e obstaculariza a sua consciência, e, por isto, a crítica e a desmistificação da religião como crítica da realidade da qual ela nasce, contribuindo, em certa medida, para a emancipação social do homem ${ }^{33}$.

Neste sentido, é mister afirmar, enfim, que nem toda religião é, ou foi, estranhamento, ocultamento das contradições do real e à serviço da exploração e da dominação; quer dizer, nem toda religião é, de uma vez para sempre, o “ópio do povo", pois cada religião ocupa um lugar e uma função específica dentro de seu contexto sóciopolítico-econômico. Por exemplo, o Cristianismo primitivo, cujos membros não eram

31 Em O Socialismo e a Religião (1905), Lisboa: Edições Avante, 1984, v. 1, p. 293 e 292, Lênin argumenta, de forma semelhante, "que a religião seja completa e incondicionalmente declarada um assunto privado." "A religião deve ser declarada um assunto privado [...]. Exigimos que a religião seja um assunto privado em relação ao Estado [...] O Estado não deve ter nada que ver com a religião, as sociedades religiosas não devem estar ligadas ao poder de Estado." Também em Sobre a Atitude do Partido Operário em Relação à Religião. Lisboa: Edições Avante, 1984, v. 1, p. 371, Lênin defende que "a religião é um assunto privado."

32 Na obra O Socialismo e a Religião (1905), op. cit., v. 1, p. 292, Lênin defende que as pessoas não devem ser perseguidas pela sua crença ou descrença, pois "Cada um deve ser absolutamente livre de professar qualquer religião que queira ou de não aceitar nenhuma religião, isto é, de ser ateu [...]”.

33 Sobre isto cf. Zur Kritik der hegelschen Rechtsphilosophie. Einleitung, op. cit., p. 379, na qual Marx enfatiza: "A crítica da religião desiludiu o homem, para que ele pense, aja, construa a sua efetividade como um homem sem ilusões, um homem que chegou à idade da razão, para que gravite em volta de si mesmo, isto é, do seu sol efetivo. A religião não passa do sol ilusório que gravita em volta do homem enquanto o homem não gravita em volta de si mesmo."

\begin{tabular}{|l|l|l|l|l|}
\hline Q Povista Dialectus & Ano 5 & n. 12 & Janeiro - Julho 2018 & p. 8-35 \\
\hline
\end{tabular}




\section{A FUNDAMENTAC̄̃̃O SUBJETIVA E SOCIAL DA RELIGIÃ̃O...}

Eduardo F. Chagas

chefes nem profetas, mas os banidos socialmente, os subjugados e dispersos por Roma, os privados de direitos, os pobres, os escravos, os perseguidos, os oprimidos e não tinham privilégios, nem propriedades, pregavam um Evangelho da libertação da servidão e da miséria, da supressão dos privilégios, das diferenças de riqueza, da fraternidade e da igualdade. Tal Cristianismo nascente queria, partindo da igualdade dos homens perante Deus, restabelecer a igualdade civil, a igualdade entre os membros da comunidade social-política. Portanto, o Cristianismo primitivo, "o humilde Cristianismo dos primeiros séculos", despojado de propriedade privada, oferecia, pelo menos a nível ideal, fundamentos para pôr em questão as instituições e ideias que são comuns às formas de sociedade que se baseiam sobre os antagonismos de classe. Embora Engels, em Der deutsche Bauernkrieg (A Guerra dos Camponeses Alemães) (1850), chame a atenção, é claro, para os limites dessas "antecipações comunistas" do Cristianismo primitivo: "Os ataques contra a propriedade privada, a reivindicação da comunidade dos bens, deviam desagregar-se numa organização grosseira da caridade; a vaga igualdade cristã podia, no máximo, conduzir à igualdade civil perante à lei [...]. A antecipação, pela fantasia, do comunismo era, na realidade, uma antecipação das relações burguesas modernas." ${ }^{34}$ Mais adiante, na mesma obra, Engels diz que essas ideias foram expressas mais nitidamente só no século XVI pelo teólogo e agitador político Thomas Münzer: "É só com Münzer que essas ressonâncias comunistas se tornam a expressão de aspiração de uma efetiva facção da sociedade. Só com ele é que são formuladas com uma certa determinidade e, depois dele, encontramo-las em todos os grandes levantamentos populares, até que se fundem, pouco a pouco, com o movimento operário moderno.”35 A teologia de Münzer expressa, na opinião de Engels, o desejo do regresso do Cristianismo à sua origem, por isto suas ideias são antecipações, em germe, das condições para a emancipação do homem, pois Münzer defende que, assim como não há céu no além, não existe também inferno nem condenação eterna e que é tarefa dos crentes realizar "o céu" na terra, o "reino eterno de Deus" no reino temporal dos homens. ${ }^{36}$ Mas, o "reino de Deus" para ele é, precisamente, uma sociedade em que não

34 ENGELS, F. Der deutsche Bauernkrieg. In: Marx/Engels, Werke (MEGA). Berlin: Dietz Verlag, 1960, v. 7, p. 346.

35 Ibid., p. 346-47.

36 Uma exposição interessante sobre o confronto entre esses dois mundos inconciliáveis, o plano humano (das trevas) e o plano divino (da luz), entre a cidade terrena e a cidade celeste, entre a ordem temporal (a história) e a ordem eterna (a eternidade), se vê na análise de Giorgio Agamben acerca do juízo processual do prefeito romano da província da Judeia, o pagão Pôncio Pilatos, que é do mundo dos homens, contra Jesus, cujo reino não é daqui, "não é deste mundo": "No processo que se passa diante

\begin{tabular}{|l|l|l|l|l|}
\hline Qevista Dialectus & Ano 5 & n. 12 & Janeiro - Julho 2018 & p. 8-35 \\
\hline
\end{tabular}




\section{A FUNDAMENTAC̄̃̃O SUBJETIVA E SOCIAL DA RELIGIÃ̃O...}

Eduardo F. Chagas

houvesse diferenças de classe, nem propriedade privada, nem poder de Estado estranho, oposto aos membros da sociedade, isto é, um mundo social novo, uma nova forma de organização social em que todos os trabalhos e todos os bens fossem comuns e que reinassem a liberdade e a igualdade mais plena entre os homens.

\section{REFERÊNCIAS}

AGAMBEN, Giorgio. Pilatos e Jesus. São Paulo: Boitempo Editoral, 2014.

ALVES, Rubem Azevedo. O suspiro dos oprimidos. São Paulo: Paulus, 1999.

BENJAMIN, Walter. O capitalismo como religião. São Paulo, Boitempo, 2013.

BETTO, Frei. Fidel e a religião. São Paulo: Editora Brasiliense, 1986.

Cristianismo e marxismo. Rio de Janeiro: Editora Vozes, 1986.

BORON, A. A teoria marxista hoje: problemas e perspectivas. São Paulo: Expressão Popular, 2006.

CHAGAS, Eduardo F. Natureza e liberdade em Feuerbach e Marx. Campinas: Editora Phi, 2016.

"A vontade é livre? Natureza e ética em Ludwig Feuerbach". In: Dialectus -

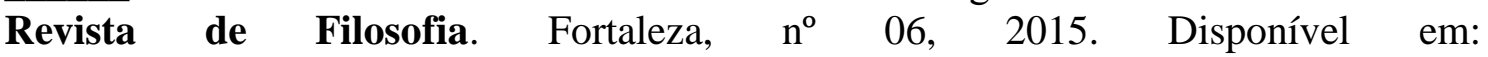
http://www.revistadialectus.ufc.br/index.php/RevistaDialectus.

"A religião em Feuerbach: Deus não é Deus, mas o homem e/ou natureza divinizados". In: Dialectus - Revista de Filosofia. Fortaleza, nº 04, 2014. Disponível em: http://www.revistadialectus.ufc.br/index.php/RevistaDialectus.

"Hegel e Marx: o caráter formal-abstrato dos Direitos Humanos", in: Filosofia e Direitos Humanos. Série Filosofia, v. 4, Fortaleza: Editora UFC, 2006, p. 249-68.

“A aversão do cristianismo à natureza em Feuerbach”. Philósophos - Revista de Filosofia, v.15, nº 2, Goiânia-Go, 2010.

Homem e natureza em Ludwig Feuerbach. Série Filosofia, $n^{\circ}$ 8, Fortaleza: Edições UFC, 2009.

de Pilatos, [...] dois julgamentos e dois reinos parecem confrontar-se: o humano e o divino, o temporal e o eterno. Com sua habitual vivacidade, Spengler expressou essa contraposição: "Quando Jesus é levado diante de Pilatos, dois mundos estão imediata e inconciliavelmente frente a frente: o dos fatos e o das verdades, e com tão assustadora clareza como nunca noutro lugar na história do mundo." "E é o mundo dos fatos que deve julgar o da verdade, o reino temporal que deve pronunciar um julgamento sobre o Reino eterno." Mais adiante, diz Jesus: "O meu reino não é deste mundo (...). Se o meu reino fosse deste mundo, os meus servos teriam combatido por mim, a fim de que eu não fosse entregue aos judeus. Ora, meu reino não é daqui". Pilatos pergunta a Jesus: "De onde és?", in: Pilatos e Jesus. São Paulo: Boitempo Editoral, 2014, p. 34, 37, 38, 42 e 44.

\begin{tabular}{|c|c|c|c|c|}
\hline Qenista Dialectus & Ano 5 & n. 12 & Janeiro - Julho 2018 & p. $8-35$ \\
\hline
\end{tabular}


A majestade da natureza em Ludwig Feuerbach. In: Homem e natureza em Ludwig Feuerbach. Série Filosofia, nº 8. Fortaleza: Edições UFC, 2009.

"A razão em Feuerbach como base da unidade do homem e da natureza". Princípios - Revista de Filosofia, v.14, nº 21, Natal-RN, jan./jun. 2007.

"Feuerbach e Espinosa: Deus e Natureza, dualismo ou unidade?" Trans/Form/Ação - Revista de Filosofia, v. 29, nº 2, São Paulo-SP, 2006.

"A questão do começo na filosofia de Hegel - Feuerbach: crítica ao começo da filosofia de Hegel na Ciência da lógica e na Fenomenologia do espírito. In: Revista Eletrônica de Estudos Hegelianos, v. 2, nº 1, Recife-PE, 2005.

Religião: o homem como imagem de Deus ou Deus como imagem do homem? In: Formação humana: liberdade e historicidade. Ercília Maria Braga de Olinda (Org.). Fortaleza: Edufc, 2004.

A autonomia da natureza em Ludwig Feuerbach. In: Filosofia, educação e realidade. José Gerardo Vasconcelos (Org.). Fortaleza: Edufc, 2003.

IJUÍ, 1998.

A comunidade ilusória: a teoria do estado no jovem Marx. Porto Alegre:

" "A cisão do mundo ético: lei divina e lei humana na Fenomenologia e na Antígona". In: Revista de educacão e filosofia, n’. 15, Uberlândia-MG 1994, S. 67-74.

"Projeto de uma nova filosofia como afirmacão do homem em Ludwig Feuerbach". In: Teoria \& Praxis - Revista de Ciências Humanas e Política, $n^{\circ}$. 4, Goiânia-GO 1992, p. 31-36.

CHAGAS, Eduardo F.; Redyson, Deyve. Ludwig Fuerbach: filosofia, religião e natureza. São Leopoldo, Editora Nova Harmonia, 2011.

ENGELS, F. Der deutsche Bauernkrieg. In: Marx/Engels, Werke (MEGA). Berlin: Dietz Verlag, 1960, v. 7.

Ludwig Feuerbach und der Ausgang der klassisiche deutsche Philosophie. Werke (MEGA). Berlin: Dietz Verlag, 1960, v. 21. 1960, v. 20.

Dialektik der Natur. In: Marx/Engels, Werke (MEGA). Berlin: Dietz Verlag,

FEUERBACH, L. Zur Beurteilung der Schrift "Das Wesen des Christentums". Org. por W. Schuffenhauer, GW 9, Berlin: Akademie-Verlag, 1970.

Vorlesungen über das Wesen der Religion. Org. por W. Schuffenhauer, GW

6, Berlin: Akademie-Verlag, 1967.

\begin{tabular}{|l|l|l|l|l|}
\hline Qevista Dialectus & Ano 5 & n. 12 & Janeiro - Julho 2018 & p. 8-35 \\
\hline
\end{tabular}


Das Wesen des Christentums. Org. por W. Schuffenhauer, GW 5, Berlim: Akademie-Verlag, 1973.

Para a crítica da filosofia de Hegel. Edição Bilíngue. Tradução: Adriana Veríssimo Serrão. Apresentação: Eduardo Chagas e Deyve Redyson. São Paulo: LiberArs, 2012.

FREUD, Sigmund. Totem und Tabu. In: Studienausgabe, Frankfurt am Main. Fischer Taschenbuch Verlag, 2000, band. IX.

Die Zukunft einer Illusion. In: Studienausgabe, Frankfurt am Main. Fischer Taschenbuch Verlag, 2000, band. IX.

Der Mann Moses und Die Monotheistiche Religion. In: Studienausgabe, Frankfurt am Main. Fischer Taschenbuch Verlag, 2000, band. IX.

G. COTTIER, O. P. Cristãos e marxistas - diálogo com Roger Garaudy. Porto: Brasília Editora, 1968.

GARAUDY, Roger. Deus é necessário? Rio de Janeiro: Jorge Zahar Editor, 1995.

O marxismo no século XX. São Paulo: Paz e Terra, 1974.

HECKTHEUER, Fábio Rychecki. A religião em Feuerbach e Marx: perspectivas para uma releitura. Dissertação. Pelotas: PUC, 1993.

LACROIX, Jean. Marxismo, existencialismo, personalismo: presença da eternidade no tempo. São Paulo: Paz e Terra, 1967.

LAFARGUE, Paul. Por que crê em Deus a burguesia? Disponível em: https://www.marxists.org/portugues/lafargue/1906/deus/

A religião do capital. Rio de Janeiro: Editora Achiamé, s/d.

LÉNIN, V. I. O socialismo e a religião. Lisboa: Edições Avante, 1984, v. 1.

Sobre a atitude do partido operário em relação à religião. Lisboa: Edições Avante, 1984, v. 1.

LÖWY, Michael. A guerra dos deuses: religião e política na América Latina. Rio de Janeiro: Vozes, 2000.

“Marxismo y religión: opio del pueblo?”. In: La teoria marxista hoy problemas y perspectivas. Buenos Aires: Editora Clacso, 2006.

LUCKMANN, Thomas. A religião invisível. São Paulo: Loyola, 2014.

LUKÁCS, György. La religione come estraniazione. In: Ontologia dell'essere sociale. Roma: Editori Riuniti, 1981, v .2.

\begin{tabular}{|c|c|c|c|c|}
\hline Rovista Dialectus & Ano 5 & n. 12 & Janeiro - Julho 2018 & p. $8-35$ \\
\hline
\end{tabular}




\section{A FUNDAMENTAC̄̃̃O SUBJETIVA E SOCIAL DA RELIGIÃ̃O...}

Eduardo F. Chagas

LUXEMBURGO, Rosa. O socialismo e as igrejas: o comunismo dos primeiros cristãos. Rio de Janeiro: Editora Achiamé, 1980.

MARX, K. Ökonomisch-philosophische Manuskripte aus dem Jahre 1844. Marx/Engels, Werke (MEGA), Bd. 40. Dietz Verlag, Berlin, 1990.

Zur Kritik der hegelschen Rechtsphilosophie. Einleitung. In: Marx/Engels, Werke (MEGA). Berlin: Dietz Verlag, 1957, v. 1.

“Nr. 179 der Kölnischen Zeitung” ("Editorial do $N^{\circ} 179$ da 'Gazeta de Colônia"”) (1842), in: Marx/Engels, Werke (MEGA), Berlin: Dietz Verlag, 1957, v. 1. 1957, v. 1.

Zur Judenfrage. In: Marx/Engels, Werke (MEGA), Berlin: Dietz Verlag,

Thesen über Feuerbach. In: Marx/Engels, Werke (MEGA). Berlin: Dietz Verlag, 1958, v. 3.

v. 23.

. Das Kapital. In: Marx/Engels, Werke (MEGA). Berlin: Dietz Verlag, 1962,

Differenz der Demokritischen und Epikureischen Naturphilosophie. in: MARX/ENGELS, Werke (MEGA), Ergänzungsband, Erster Teil, Berlin: Dietz Verlag, 1968.

Kritik der Politischen Ökonomie. In: Marx/Engels, Werke (MEGA). Berlin: Dietz Verlag, 1983, v. 13.

MARX, K/ ENGELS, F. Die deutsche Ideologie. In: MARX/ENGELS, Werke (MEGA). Berlin: Dietz Verlag, 1958, v. 3.

Manifest der Kommunistischen Partei (Manifesto do Partido Comunista) (1848), in: Marx/Engels, Werke (MEGA), Berlin: Dietz Verlag, 1959, v. 4.

MARX, K./ENGELS, F. Sobre a religião. Lisboa: Edições 70, 1972.

MICHAELS, Axel. Klassiker der Religionswissenschaft - Von Fredrich Schleiermacher bis Mircea Eliade. Darmstadt: Wissenschaftliche Buchgesellschaft, 1997.

MINOIS, Georges. História do ateísmo. São Paulo: Editora Unesp, 2014.

MONDIN, Battista. Quem é Deus? Elementos de teologia filosófica. Tradução José Maria de Almeida. São Paulo: Paulus, 1997.

MOTA, Francisco Alencar: "Marx e a religião: pressupostos básicos para uma compreensão da religião na obra de Marx." In: Dialectus - Revista de Filosofia. Fortaleza, nº 04, 2014.

\begin{tabular}{|l|l|l|l|l|}
\hline Qovista Dialectus & Ano 5 & n. 12 & Janeiro - Julho 2018 & p. 8-35
\end{tabular}




\section{A FUNDAMENTAĈ̃O SUBJETIVA E SOCIAL DA RELIGIÃO...}

Eduardo F. Chagas

NIETZSCHE, F. David Strauss: sectário e escritor. São Paulo: Escala, 2008.

PORTELLI, Hugues. Gramsci e a questão religiosa. São Paulo: Paulinas, 1984.

PROENÇA, Eduardo de (org.). Apócrífos e pseudo-epígrafos da Bíblia. São Paulo: Fonte Editorial, 2005.

RAWIDOWICZ, S. Ludwig Feuerbachs Philosophie - Ursprung und Schicksal. Berlin: Walter de Gruyter \& Co, 1964.

VATTIMO, Gianni. Depois da cristandade - por um cristianismo não religioso. Rio de Janeiro: Record, 2004.

VERRET, Michel. Os marxistas e a religião - ensaio sobre o ateísmo moderno. Lisboa: Prelo Editora, 1975.

XENOPHANES. Fragmente - Vorsokratiker. Org. por W. Capelle, Stuttgart: Reclam, 1968.

WEBER, Max. A ética protestante e o espírito do capitalismo. São Paulo: Abril Cultural, 1980 (Os Pensadores).

Rejeições religiosas do mundo e suas direções. São Paulo: Abril Cultural, 1980 (Os Pensadores).

WEISCHEDEL, Wilhelm. Der Gott der Philosophen - Grundlegung einer Philosophischen Theologia im Zeitalter des Nihilismus. Darmstadt: Wissenschaftliche Buchgesellschaft, 1983. 